\title{
Mystical Ars Amand: Considerations Based on the Texts of Meditation Literature of the 17th and 18th Centuries
}

\author{
Beata Lukarska \\ Institute of Literary Studies, Faculty of Humanities, Jan Długosz University in Częstochowa, Częstochowa, Poland
}

\section{Email address:}

b.lukarska@ujd.edu.pl

\section{To cite this article:}

Beata Łukarska. Mystical Ars Amand: Considerations Based on the Texts of Meditation Literature of the 17th and 18th Centuries. American Journal of Art and Design. Vol. 6, No. 3, 2021, pp. 103-111. doi: 10.11648/j.ajad.20210603.15

Received: July 18, 2021; Accepted: August 27, 2021; Published: September 6, 2021

\begin{abstract}
The present article discusses the literary, linguistic, cultural, and spiritual qualities of unknown or forgotten monuments of ancient Polish literature. It also constitutes an attempt to prove the universalism of the art of the word. The analysis of messages of meditative and mystical literature of the 17th and 18th centuries provides a basis for this study. Most of the quoted records remain anonymous. However, it can be said with certainty that their authors were both women and men. It is worth noting that the quoted texts from meditative and mystical literature were composed in different spiritual traditions, including both the Carmelite and Benedictine spirituality. In particular, the author's research interests focused on how the writers of ancient mystical and meditative literature presented the art of love, both in terms of spiritual love (the relationship between God and man) and universal love that involves every dimension of the world we live in (the relationship between men themselves and between man and the world). A historical and literary analysis, which seems an indispensable tool for research on ancient Polish literature, has been applied to the study. The history of spirituality and old culture serves as a background for literary reflections. The literary and artistic quality of the quoted texts can be detected in numerous cultural references, literary references, a rich diversity of symbolism (the symbolism of the heart, symbolic images presenting intimacy between two people in love), diverse forms of expression (a dialogic structure of texts, an intimate inner monologue), an artistic depiction (the role of imagination). The conducted analysis has allowed the author to demonstrate the universality and timelessness of ideological and cultural messages of Polish mystical and meditative literature. Furthermore, it has been proven that the art of the word presented in the records is rooted neither in one national tradition nor in one language nor one culture. Although the texts date back to a remote period, they still present the universal beauty of the art of thought and the art of the word.
\end{abstract}

Keywords: Mystique, Meditation, Love, Monastic Contemplation, Prayer, Christian Tradition

\section{Between the Spirit and the Word}

Christian meditative prayer (sometimes also called mental or inner prayer) has its centuries-long history. However, the 17th century, which is the perspective of the present reflection, refers mainly to the achievements of four schools of spirituality, namely: the Benedictine (St. Benedict and his followers) [22, 44], the Ignatian (St. Ignatius Loyola, the Jesuits) [40, 29], the Carmelite (St Teresa of Ávila, St John of the Cross) [47, 27, 28] and the Salesian (Francis de Sales) [31].

The presented study will discuss two dimensions of art: the art of thought and the art of the word; or, to put it more precisely, the art of meditation (ars meditandi) and the art of expressing the love that springs from it, of naming love as (ars amandi). Consequently, let us start with the art of meditation, understood by many as a special kind of prayer (in the sense of the specificity of the act of faith) because it engages the entire personality of men in their spiritual, rational, volitional, emotional and sensual dimensions [43, 41]. It is a prayer that leads to a closer union with God, awareness of his presence, and reality, which ultimately becomes the realization of a higher level of meditation, which is contemplation.

The discussed historical records of meditation texts define the meaning of prayer and, at the same time, become their more or less perfect models.

In terms of definition, the seventeenth and eighteenth-century meditations contain the terms that, on the one hand, are derived from the thoughts of the Fathers of the Church - precisely from the indications of such figures of the Christian past as: St. Gregory of Nysa (4th century), St. John 
Chrysostom (4th/5th century), or St. John of Damascus ( 7 th/8th century), on the other hand, they remain universal in their basic form, and therefore valid to this day. They include statements that describe prayer as elation, the act of raising one's mind to God, raising one's heart to God, speech directed towards the person of God, conversation, dialogue with God, playing with the beloved (God), mystical intimacy, engaged mutual involvement, a conversation full of mutual love. In the deliberations on this matter, in the accounts written by 17th-century Polish authors, more detailed references refer to various aspects of the prayerful commitment. According to one of these indications in the art of reflection, it is the relevant matter of thought that becomes essential. It is defined as food for the soul obtained from the work of the mind, just like food for the body obtained from grain of excellent quality, ground in the quills of a water mill, because "our reason is as a mill, what one sows, it grinds" [18] ${ }^{1}$. Other Polish baroque authors of meditation texts pay attention to the need to stimulate the will and feelings because prayer (meditation) is: "raising the heart to the Lord God present" [13]; to maintain purity and integrity in the dimension of the soul, heart and body - in a meditative prayer because: ,a pure heart and body are lifted to God" [3]; and for the necessary detachment of the heart from worldly things and focusing it on meditating on supernatural things, because: „worldly affection steals the heart, without which [...] no one can pray" [21].

The appropriate preparation of the meditator also seems essential as it is described as the preparations made by those in love before the nuptials, i.e. the wedding feast. As God:

[...] na godach dusznych niedostatku duchownego, defektu wina, to jest defektu gorącości ferworu, oziębłości dusznej, nierad widzi i do takowych dusz oziębłych, w cnoty święte ubogich nie rad przychodzi ([...] sees no joy in festivities of the souls of spiritual insufficiency, the defect of wine, that is, the defect of heat of fervor, soul frigidity, and does not welcome such frigid souls in the holy virtues of the poor) [15].

The ancient meditative messages also become a record of the successive stages of the path of meditation and their internal order, some taking on the shape and composition of a practical guide for meditators of specific spiritual content [46].

As already mentioned, meditative prayer - through successive stages of mental, volitional and emotional involvement - leads the praying man to meditative states, most often defined as experiencing the presence of God himself, or - referring to, as one of the analyzed Old Polish records - to "stałego i gruntownego przez miłość z Bogiem złączenia" ("constant and thorough union with God through love") [21].

Contemplation thus aims at a higher level of the union of the soul with God on the intellectual-volitional path, the culmination, the highest stage of which may be mystical

1 Citations from manuscript texts are given in the attached bibliography under double identification, in the sense of a reference and, where there is a title, also the title of these records. ecstasy $^{2}$, also called "the Rapture" or "rapture to the hilt" in the old language, in which "inexpressible delight grazes the appetite, and with the appeasement of the superior senses it grows, and all the soul seeks to taste this delight [...]" [1].

Mystic nuns are especially predisposed to the ecstatic states defined in this way. In biographies, memoirs, and minor remarks made on the margins of the meditation texts they left behind, they also noted moments of this mystical union with the beloved God. Moments full of happiness and loving communion with the Creator's closeness are described, for example, by the sixteenth-century nuns: St. Teresa of Ávila [27, 35, 45] and St. Maria Magdalena de'Pazzi [32].

Nowadays, they are repeatedly mentioned by St Faustyna Kowalska, who is also known outside the geographical borders of her Polish homeland [23] $]^{3}$.

Therefore, treating the art of meditation as the art of talking about love, or more adequately: the art of expressing love, we will close the entirety of the topic in two subsequent parts: the first one relating to the linguistic way of declarative feelings, and the second, which will be about visualization in the sense of the technique of images evoking the scenery of the extrasensory, contemplative connection of the soul with the closeness of the beloved God that manifests itself in it.

As a complement to the present introduction, the reader should also receive information about the origin of the source texts that form the basis of this study. These are primarily anonymous monastic manuscripts, written from the end of the 16 th century to the middle or last decades of the 18th century. They are connected by subject matter, and they are distinguished by the represented spirituality, which accentuates the essential truths of the Christian faith tradition in a slightly different way. In addition, all the historical records cited in the article are part of a numerically significant collection of manuscripts of the National Ossoliński Institute in Wrocław.

\section{Words (About) Love}

The ancient masters of the word often make "love", in the sense of mystical love and spiritual love, one of the most important subjects of their meditations. The 12th-century Cistercian monk Bernard of Clairveaux ${ }^{4}$ mentions love as a necessary dimension of intimate human closeness to God in his writings. Several centuries later, this truth is confirmed in the famous treatise On the Imitation of Christ by the 14th-century Dutch monk of the Order of Canons Regular of

\footnotetext{
${ }^{2}$ Father Jerzy Misiurek, an expert in this issue, defines ecstasy as love granted by God, filling the will and mind of man and extending to his whole spirit [39].

3 These moments of raising the soul to God and complete detachment from reality are so numerous in the message of St Faustina that the entire Diary of the saint can be considered a description of constant closeness to God. For this reason we do not give the pages of that publication.

4 The words from one of St Bernard of Clairveaux's treatises read thus: "Reason and a natural sense of justice induce man to give himself to the love of Him to whom he owes himself and everything. As for me, faith commands me to do much more: to love God not only for having created me, but also for having given me himself" [24].
} 
St Augustine - Thomas à Kempis ${ }^{5}$, who was brought up by "the Brethren of the Common Life". Moreover, the first of them describes this regularity that meditations evoke supraand extra-sensual realities, referring, however, to the language proper to the speech of the senses. In this spirit, Bernard of Clairveaux, directing his words to an unspecified addressee of his reflections, writes:

Dusza nasza - jak Ci wiadomo - widzi oczami, słyszy uszami, czuje powonieniem, smakuje podniebieniem, dotyka ciałem (Our soul - as you know - sees with eyes, hears with ears, smells, tastes with the palate, touches with the body) [24].

Similarly, the later seventeenth and eighteenth-century reflections quoted in this study show mystical love, manifested in acts of meditation and then contemplation, as a state in which the meditating person experiences what often exceeds the natural limits of his senses, crosses the natural boundaries of his body. Yet, at the same time, the same experiences are expressed by the meditators in what remains closest to them, i.e. paradoxically in body language and the speech of the senses.

In the spirit of this principle, the meeting of man with God in acts of mystical closeness is often described as a meeting of lovers, a mystical conversation, a conversation between ,the lover and the beloved one", or a mystical meeting of lovers longing for their closeness.

In the set of popular linguistic designations for this mystical intimacy between the soul and God, there appear terms related to the sense of taste: love is tasty, sweetly delicious; with the sense of taste and smell: love is as delicious as old wine, tastes like fine balsamic vinegar, love is fragrant and scented like rose water of which those who love each other smell.

Love also becomes a way to quench your thirst and hunger; you can fill yourself with it spiritually, you can nourish yourself with love, drink love like wine "from a cup of love", you can enjoy it and finally also drink it healthily. Besides, Jesus, as a mystical lover, is "more faithful and younger" for the soul [19].

At the same time, several stages precede proper conversation of the soul of man with God. First, the scene of invoking God on the part of the soul, implemented stylistically in the accumulation of characteristic forms of expression such as invocations-apostrophes ${ }^{6}$, commonly expressing longing, impatience, expectation and "longing sighs" [12]. On the other hand, the coming of God seems to require prior preparation of the heart because - like the mystical Bridegroom - he wants to speak not to the ear and not through the ears, but to the heart and soul of his chosen one. This truth is confirmed by

\footnotetext{
5 An extract from the work of a medieval thinker: "On the Imitation of Christ": "Thou hast most shown me the graciousness of Thy love by the fact that I was not, and behold, Thou hast created me, I wandered so long, and behold, Thou hast brought me to Thyself to serve Thee, and Thou hast taught me to love Thee" [25]. 6 In Polish linguistic research it is emphasized that the apostrophizm indicated is an element characteristic for statements maintained in the style of religious utterance (in the broader sense), and especially in the mystical style (in the narrower sense). See. [38, 48].
}

subsequent meditation records, in which we read:

Mówić będę do serca twego, nie do ucha; lecz do serca twego chce Pan Bóg mówić [...]. Więc uprzątniej wszystkie prózność z serca twego, ozwij się zawczasu z prorokiem świętym: gotowe serce moje Panie. Mów Panie, bo słucha sługa twój (I will speak to your heart, not to your ear; but to your heart the Lord God wants to speak [...]. So cleanse all vanity from your heart, turn in advance with the Holy Prophet: my heart is ready, O Lord. Speak, O Lord, for your servant is listening) [7];

or:

Tu na koniec, niebieskiej oblubienice zaprasza duszę ulubioną sobie, aby z nim weszła w słodką komitywę i w rozmowę poufałą. Poufałą mówię, bo nie do ucha jej mówić zechce, jako zwykli poufali przyjaciele wespół z soba mówić i sekretnie rozmawiać, lecz On daleko doskonalej, bo sercem do serca naszego mówi (Finally, He invites the soul, the heavenly Bridegroom favoured by himself, to enter into sweet communion and confidential conversation with him. I say confidential, because He does not wish to speak to her ear, as ordinary intimate friends speak to each other and talk secretly, but $\mathrm{He}$ is far more perfect because He speaks with His heart to our heart) [9].

and in the following text:

Będę tej mówił do serca. Poufały przyjaciel do ucha, gdy mówi co dla przestrogi dla sekretu pilno słuchać go, pilno zachować, pilno wykonać trzeba. Nie do ucha, do serca chce Pan Bóg mówić (I will speak to this one to her heart. When a trusted friend speaks to the ear, he says something for a warning for a secret, and one should listen to, one should keep it, one should perform it. So God wants to speak not to the ear but to the heart) [16].

The response to God's demands formulated in this way are words of readiness to listen on the part of the soul, each time inscribed in the same texts of the mystical confessions, taking on, nota bene, the varied shape of rhetorical declamations: for example, a formula close to a direct, lyrical statement: „I will put my ears to my heart and listen to what it says to me..." [11]; or a statement related to the quotation of the biblical characters, King David and the prophet Samuel: „My heart is ready, my heart is ready. "My heart is ready, God my heart is ready [...]. Speak Lord; your servant is listening" " [16].

In the context of the established mystical communication between man and God, there appears a characteristic situational vocabulary, such as expressions describing the specificity of a meeting of people in love, namely: rushing to the room in which the mystical lover remains hidden, literally: "concealed" [1], "confidential glances in the eyes" [13]; intimate requests for a hug uttered in a whisper - for example, the sensitivity of a request spoken by a soul longing for the Creator's closeness: "Embrace me as close to you as possible [...]" [8], and similarly elsewhere in this message: "Embrace me to your sweetest and divine heart and have mercy on a

\footnotetext{
7 See Ps. 108, verse 2.

8 See 1 Sam. 3,3 .
} 
miserable creature" [8]; and the encouragement to kiss and finally the coveted embrace in the arms of the mystical Bridegroom: "[...] so that I would be changed in you, my heartfelt joy, that I would go to you and be overwhelmed with your delight" [19].

There is also a clear metaphorization achieved in the phrases: "May I fall asleep under the cover of your love" [19] or "[...] so that I may cotton up to you and attract your liking [...] so that I may take your sorrow into my heart and hide you" [19].

Declarative confessions of everlasting love, which can take the form of longer utterances, become the final scene of these meditative experiences, a love dialogue of the soul with God, For example:

Kocham cię nad wszystko stworzenie, nad wszystkie słodyczy, nad życie i zdrowie moje (I love you above all creation, above all sweetness, the life and health of mine) [20].

or:

Ty wiesz Panie, że cię kocham ze wszystkiego serca mego (You know, O Lord, that I love you with all my heart) [10]. and yet in another text:

Kocham cię z całego serca mego. Pragnę cię kochać coraz więcej a więcej. O, gdybym miał wszystkie te serca, które cię nie kochają, wszystkiemi temi jak najgoręcej i najstateczniej bym cię kochał (I love you with all my heart. I want to love you more and more. But, oh, if I had all the hearts that do not love you, with all of them, I would love you most warmly and most thoroughly) [17].

The same function is fulfilled by the assurances of the everlasting love between the soul and its divine Bridegroom realized in mystical quasi-dialogues:

Miłujesz mię miłości? o nieograniczoności, Boże mój? A ja ani mizernie Cię nie miłuję. Więc odtąd miłować Cię będę Panie (Do you love me, my love? O unlimited, my God? And I love Thee not a little. So henceforth I will love Thee, O Lord) [6].

Similarly, in the keywords used, semantically associated with a lack of emotional involvement: "ignite", "transform", "unite", "do not abandon", "I long", "I desire", "I crave", invariably leading to the visual culmination of the utterance in the form of an imagined set of mystical weddings ${ }^{9}$ [35].

To complete the present section, it is worth noting the usual way of building the so-called nests of meaning, or series of similar symbolic meanings, the center of which are words closely related to the psychology of love. In the analyzed records of meditative texts of the late Baroque era, such terms include: "heart", "arrows" (in the sense of bow shooting, probably in the context of association with the mythical arrows of Cupid), and the opposing "fire"/"water"; the latter most often used in gradations: from the fire of the body, which

\footnotetext{
${ }^{9}$ The gift of mystical nuptials, that is, of becoming the bride of Christ himself, was bestowed upon Saint Teresa of Ávila. According to the testimony of the Sain herself, this happened on November 18, 1572, at the Convent of the Incarnation in Ávila. This is also a characteristic motif in the note under the title: On marrying God with the soul [33]
}

is fever, to the heat or fire of love; and similarly in the second case - from the thirst-saturating spring of crystalline water to the hyperbolic flood of love.

The heart as the seat of feelings was already alluded to by earlier creators of the meditative word: St. Bernard of Clairvaux, Thomas à Kempis, indicated earlier, and Blaise Pascal, St. Catherine of Siena, St. Mary Magdalene de Pazzi. Around the heart as a symbol of the mercy and love of Jesus, the tradition of the cult and devotion to the Sacred Heart of Jesus was built, which began with the revelations of the seventeenth-century nun, St. Mary Margaret Aloquoque, in the French monastery of Paray-le Monial [34, 39].

In the meditations that are the subject of this analysis, the term "heart" is most often combined with verb forms that introduce specific and symbolically repetitive actions and that create specific fixed lexical structures ${ }^{10}$. In them, you can read about the need to purify the human heart from attachment to worldly values and sin, written in the formula of the phrase-appeal: "heart, shake off the dust of sin and put yourself in God's hands [...]" [4].

Or expressed in the form of the declaration already discussed: "O my heart, tear yourself out of my bowels and change yourself into one flame of love for God, who loves me so much" [6] and in another part: "may not my heart, ceaselessly dying, live only with Thee and for Thee" [17].

There are also extended metaphors depicting the mutual wounding with arrows of love between the heart of man and the heart of God: "Thy heart also let it be always open, that with swift arrows, full of fervent love, thou mayest soar upward" [17].

Equally frequent are the symbolic acts of inviting God into the heart of man and, conversely, man into the heart of God: "Let there be my heart, and thy palace and thy bed [...]" [8]; encouragement to commemorate one another in the heart: "Jesus always carries you in his heart, and you always carry him in yours" [17]; requests for entrusting the heart: "thy God, thy Lord asks thee, Thy miserable subject asks Thee, give him Thy heart as a tribute for all this, he will be satisfied" [16]; formula of mutual presentation, mutual giving of heart: "I present this heart, my God, my only good, and declare that in it I have nothing that I love or respect above you" [7].

By way of imaginative and emotional reinforcement, the aforementioned constructions are sometimes accompanied by characteristic epithets describing the heart of the praying person as a chamber, palace, tabernacle, bed prepared by man for God who comes to him; the heart of God, on the other hand - using a semantic resemblance - an eternal dwelling, a nice "dwelling-place", or, in connection with the emotional function of the diminutive, a "small dwelling-place" for the love-thirsty heart of man [19].

The already mentioned symbolism of fire, heat and conflagration appears in the figurative meanings of actions expressed by verbs: "to ignite", "to warm" (the heart and spirit),

\footnotetext{
$10 \mathrm{It}$ is also important to remember the very clear biblical connotations of the word "heart". See [36].
} 
"to light up". The above-mentioned linguistic forms are also associated with a mechanism for triggering the imagination, for example, by means of partial associations with work in a forge in statements such as: "love that has a workshop and a fire, where it makes its fiery arrows" [19]. On the other hand, in the context of recalling supernatural images, the visions with which the French mystic Jeanne-Françoise Frémyot de Chantal, co-founder of the Order of the Visitation, popular in the Baroque era, was endowed, there appears the image of the wounded side of Jesus, from which "[...] many chains of fire come out" [19].

Christ, seen through the eyes of a mystic, is also like the sun that can warm and ultimately ignite the cold human heart [20, 2]. Moreover, the immeasurable fire of Jesus' love annihilates the sinner's transgressions, and the loving word of God melts the human heart as fire melts wax $[16,5]$.

Water as an element opposed to fire appears in the comparison of the sinner's littleness to the fire spark that destroys "in the flood of God's mercy" [19] or the same fire spark annihilated "from the flooding of great waters" [19]. The sinner pictured in the prayer of meditation also addresses his loving God with a form of hyperbolized (exaggerated) request:

Niech mię przepaść morska twojej wielkiej litości zatopi. Niechaj ginę w potopie twojej wielkiej miłości jako ginie kropla w głębokości morskiej, tak ja niechaj zginę (Let the abyss of the sea of your great mercy drown me. Let me perish in the flood of your great love, as a drop perishes in the depths of the sea, so shall I perish) [19].

Each of the groups of linguistic associations mentioned so far subsequently becomes the basis for the activation of imagination, leading to the phenomenon referred to in contemporary literary and cultural studies as visualization [37, 42] achieved in the text and through a literary text, in this case, ancient records of a meditative nature.

\section{The Imagination of Love}

The records of meditation literature analyzed in this part, which show the mechanism described in the literature of the subject by the above-mentioned terms (visualization, vision, imaginativeness or activation of imagination), can be divided into three groups. The first of them, probably the most frequently encountered, refer to the nuptial vision, and more precisely, to the descriptions of spiritual engagement, mystical weddings, marriage, the scenery of love intercourses in the form of a spiritual transformation of the terminology of a sexual act.

The next one, related to a certain extent to the previous one, uses the method of allusive use of commonly known and for a long time culturally present images of the biblical poem about bridal love, which has been the Old Testament Song of Solomon for centuries. The third and the last one refers to fairy-tale motifs developed in terms of scenery, magical rituals preserved in literature or, finally, scenes commonly associated with childhood experiences.

In the first of the groups mentioned, words that trigger the expression of cultural allusions become "nuptial", "nuptial soul", "engagement", "marriage", "bridal love", "bride", "bridegroom", and in the functional dimension: "to join", "to unite" (also in the allusion of a bodily act), "to use", "to paw" (meaning 'to hold in one's arms').

These verb forms appear, for example, in the note of meditation as a definition of the highest degree of intimacy of the soul wedded to the mystical Bridegroom - God, where it reads:

Trzeci stopień jest, gdy Boga przez miłość ku niemu trzymamy i obłapiamy albo do siebie przytulamy i duchownie zażywamy (The third degree is when we hold and embrace God through love for him, or hug him to ourselves and foster spiritual life) [5].

On the other hand, in the record of the meditation grown out of Carmelite spirituality, the speaking subject that is understood as a soul in love and wedded to God makes an insistent appeal (request) to the addressee of his reflections to be united as soon as possible in the expected act of the promised intimacy:

Niechże cię miłuję mego miłośnika namilszego, nich cię miłuję oblubieńca anielskiego, niech cię miłuję kochanie moje jedyne (Let me love you, my beloved lover, let me love you, angelic Bridegroom, let me love you, my only love) [8].

Or, in another part of the same literary monument:

O kiedyż mię wolnym uczynisz od potrzeb doczesności, abym cię nagimi ramionami miłości mocno obłapił i słodko na wieki trzymał ( $\mathrm{O}$ when wilt thou make me free from the necessities of mortality, that I may embrace thee with my bare arms of love, and hold thee sweetly forever) [8].

The scenario of the sexual intimacy of lovers is realized even more clearly in the following examples, namely in the quotations from the seventeenth-century Polish paraphrase of the Mystical Letters of the Spanish Carmelite Father John of Jesus and Mary (Juan De San Pedro y Ustarroz). In this case, both visual and sound imagination were strongly activated. The latter is conveyed through onomatopoeic formulas, which describe the climate of the sounds of romantic delight.

Thus, in the expressive monologue of the meditation hero, there could be utterances such as:

Dlatego pospieszał i pieścieł się z tobą Bóg nasłodszy serca twego i w zachwyceniu nasłodszym zabawiał i delektował $\mathrm{z}$ toba obficie (Therefore hastened and fretted with thee the God the sweetest of thy heart, and in the sweetest rapture he entertained and savored with thee abundantly) [26].

Albowiem oblubieniec twój, głęboko wszedłszy w cię, spojęł się $\mathrm{z}$ tobą (For thy Bridegroom, having entered deeply into thee, hath joined himself to thee) [26].

Opiewaj chwałę i wykrzykaj w rzece rozkoszy, w której cię zatopieł namilszy twój (Sing of the glory and shout in the river of delight in which thy dear one hath drowned thee) [26].

Another group of texts refers to biblical messages relatively often present in popular cultural perception, especially to the previously mentioned Old Testament Song of Solomon [30]. The specificity of building visualizations present in this kind of record consists in a subtle allusiveness sometimes based on 
a single most characteristic motif and inactivating the reader's memory update. This is what the author of the eighteenth-century meditation with the symbolic title: The Hand of God is ready to lead us to salvation... does, comparing the soul devoted to meditation to the biblical turtledove in an extensive comparison:

Uważ sobie jakobyś synogarlicą była, która osobliwie w ten czas, gdy pozbędzie przyjaciela usiądzie na suchym drzewku, nie śpiewa, ale jęczy, jakoby płaczliwym głosem pokazuje, że pozbyła swego przyjaciela. Toż właśnie czynić masz oblubienico Chrystusowa straciwszy przez zły, rozpustny żywot swego oblubieńca, a wydawaj płacz i jęczenie, na tym cały żywot trawiąc z żałością szukać swego kochanego aż go najdziesz (Think of thyself as a turtledove, which, when it loses its friend, sits down on a dry tree and does not sing but moans, as if with a weeping voice it were showing that it has lost its friend. This is what you should do, $\mathrm{O}$ bride of Christ, if you have lost your Bridegroom through a flawed, debauched life, and you should weep and groan and spend the whole of your life in mourning and searching for your beloved until you find him) [16].

There are two subtle references to the above-mentioned biblical poem, namely: the comparison of the beauty of the soul-bride to the beauty of the bird - a symbol of innocent bridal love ${ }^{11}$, and the comparison of its yearning voice to the voice of the one who suffers separation from her beloved.

In the following quotation, the reference to imaging the Song of Solomon, or more precisely to the passage from Book 3 , verses 2 to 4 , is more explicit. It is a kind of paraphrase of the biblical message, as it reads:

Szła dusza z największym pieczołowaniem przez różne dyskursy i medytacyje, to abowiem znaczą te słowa: obieżę miasto po ulicach i rynkach [...]. I zda się nie znalazła go tak doskonale jako ona pragnęła, gdy go przez medytowanie i przez dyskurs i operacyje albo pracą rozumu szukała. Lecz maluczko odszedszy od nich [...] afektem sobie wyznawa, iż oblubieńca swego niebieskiego znalazła (The soul experienced with the utmost concern various discourses and meditations, for that is what these words mean: I will go round the city streets and markets [...]. And it seems that she had not found him as perfect as she had wished when she searched for him through meditation and discourse and operations or with the work of her mind. But having left them a little while ago [...], she passionately admits to herself that she has found her heavenly Bridegroom) [5].

In the seventeenth-century text, the role of the biblical heroine who seeks her lost beloved with great diligence (in the text, it is expressed as "with the utmost concern") is played by the soul of the meditating man. Later in the record, the author recalls the scene of the meeting of the biblical bride with the guards who go around the city. Their characters become the starting point for an extended parabola. Indeed, the guardians of the city walls are operations of the mind, a path of the inner discourse that will not indicate the whereabouts of the

11 See Song 2, 12 personal God, just as the city guards encountered did not reveal the concerned bride the place where her Bridegroom had gone. The conclusion of this parabolic paraphrase strengthened by the effect of visualization is the teaching contained in the final sentence of the quotation: the bride-soul, like the biblical bride, will find her beloved (read: God) not by the effort of reason and rational discourses, but by "affect", that is, with the action of the heart.

The Old Testament stories find their imaginative processing in two more accounts. There is a laconic, true to form, in each, reference to the history of the chosen people, precisely to the circumstances of the capture of the biblical Jericho. In the first one, the author of the meditation compares the paths of the meditator's thoughts that wander from earthly matters towards the reality of heaven to the spy expeditions sent to Jericho by the leader of the Jewish warriors, Joshua ${ }^{12}$ [5]. In the second meditation, the meditator's heart is compared to the biblical Promised Land and Jericho, the Canaanite stronghold blocking the Chosen People from final reaching the space of Canaan [11].

The last of the initially mentioned tradition of meditation records is made up of messages referring to motifs that could be described as fairy-tale-magical.

The first of the quotations listed below activate the acute sense of smell, moving the viewer's attention to the circle of ideas that are semi-realistic, semi-magical, evoking the images of the workshops of former masters of perfumery with machines for distilling various fragrances ${ }^{13}$ or old cellars where valuable wine was stored or where fragrant balsamic vinegar matured according to age-old recipes. In the text referred to, the intensity of the fragrance of these three precious ingredients is compared to the sweetness that comes from getting close to Jesus, or more precisely to "the pharmacy of His sweetest Heart":

Pociągni że mię nasłodszy Jezu mój za sobą, na zapach maści twoich pobieżymy w tym słowie [...]. Pierwsza jest wódka różana, którą miłość boska z jak nazacniejszej onej różej, to jest boskiego serca w piecyku umiłowania przepuściła. Tej wódki zażywaj na omycie twarzy dusze twojej, co rozpamiętywając sobie pilno, jeślibyś jaką zmazę grzechu na niej znaleźć mogła, którą proś, aby omyta była z onego źrzódła miłosierdzia, z którego łotr omyty był na krzyżu. Wtóra jest ono wino czerwone to jest krew przenaświętsza, którą prasa wycisnęła na krzyżu i wodę wywiodła $z$ rany różanej serca jego, z której proś, aby dusze twojej twarz przyfarbowana była, żebyś do takiej uczty godnie mogła bydź przysposobiona. Trzecia jest przewyższająca i przelewająca się boskiego serca nieoszacowana słodkość, której ani gorzkość śmierci umniejszyć nie może i nie mogła i zowie się balsamowym

\footnotetext{
12 See Josh. 2, 1-24.

13 These subtle descriptions of old interiors are triggered more strongly when we realize their similarity to the peculiar reconstruction of an old perfumer's workshop from the 1985 novel Perfume by the German writer Patrick Süskind. The novel by the contemporary author can also be defined as a story-metaphor about searching for the sources of the longed-for love.
} 
olejkiem przewyższającym wszelki korzenny zapach i pomocny jest na wszelaką słabość naszę duszną (Draw me, my sweet Jesus, to the fragrance of Thy ointments, let us run in this word [...]. The first is the rose vodka, which God's love has poured into the furnace of love from the most precious rose, which is your divine heart. Take this vodka to wash the face of your soul, mindful of the stain of sin upon it, which you ask to be washed from the same fountain of mercy from which the thief was washed on the cross. The second is the red wine, the holy blood, which the press impressed on the cross, and the water that came out of the rosebud of his heart, from which ask that your soul's face may be tinted, that you may be worthily prepared for such a feast. The third is surpassing and overflowing of the divine Heart, an inestimable sweetness, which neither the bitterness of death can and could diminish, and is called balsam oil, reaching every spicy fragrance, and is helpful for all our soul's weakness) [19].

Another text worth quoting here activates the sense of sight. It opens up the perspective of inner vision, building in the recipient's imagination a setting, which could be compared to the final scene of Tolkien's tale of the fate of the Fellowship of the Ring. Or, more precisely, to the moment of the destruction, melting of the ring which is the material expression of desire and evil, in the fire of the so-called Mount Doom. In the seventeenth-century meditation, the magic ring of evil powers is man's bodily, sensual and spiritual weaknesses; the fire burning in the mystical "Mount Doom" is "the abyss of God's fiery love". The meditator thus confesses:

Otóż tedy wpuszczam i wrzucam tę całą odrobinę istoty mojej w tę przepaść ognistą miłości twojej, roztop-że i rozpuść, straw i zniszcz, przemień i przeistocz wszystko to, com ja jest $\mathrm{w}$ to wszystko coś ty jest [...]. O szczęśliwa substancyja $\mathrm{i}$ istoto moja, w który do takiej przemiany przyszła, żeś się przerodziła w miłość Pana Jezusa ukrzyżowanego, żeś się przemieniła w Jezusa umęczonego, żeś jest pożarta od ognia miłości Jezusa za cię umarłego Therefore I let and cast this little bit of my being into the fiery abyss of your love, melt and dissolve, digest and destroy, transform and change all that I am into all that you are [...]. O happy substance and my being, in whom it came to such a transformation that you were transformed into the love of the Lord Jesus crucified, that you were transformed into Jesus the Passionate, that you are consumed by the fire of the love of Jesus who died for you [19].

Another of the records recalls the fairy-tale motif of transforming a poor peasant girl into the chosen one of the heart of a great king. The phrase: "Think [...] as if you were a poor little peasant girl" - invites the meditator to enter into the role of a poor woman who, in some miraculous and unforeseen way, has not only been bestowed with the love of a monarch, but, moreover, has been introduced into his palace, dressed in the clothes worthy of a royal wife and, finally, invited to share the royal life of her beloved from now on:

Pomyśl sobie, jakobyś jedna nędzna, podło ubrana uboziuchna kmiotówna była, którą król wielki na pałac i do pokoja swego wprowadzić kazał i aby zdjąwszy łachmaniny po królewsku się ubrała i tak przybrana znosiła się z królem i rozmawiała sobie o rzeczach poważnych, osobliwie o tym jakoby dożywotnią i wieczną jego oblubienicą była (Think how you would have been if you had been a poor, shabbily dressed peasant girl, whom the great king had ordered to be brought into his palace and room, and that, having taken off her rags, she had dressed royally and, thus attired, had met with the king and talked to him about serious matters, especially about how she had been his lifelong and eternal bride) [16].

In the same circle of cultural and sensual imagery, there remains the visionary scenario of building a royal palace. The king for whom the castle is constructed is God himself. The role of the builder laying the foundations, erecting the walls, building the roof, chimneys, vents, stairs, furnishing the interior of the palace chambers and finally, at the end of the story, lighting the "fire of love" in the palace fireplace, is played by the soul of the meditating

The messages activating the cultural memory of childhood motifs include an image resembling the setting of a tender father putting a child to sleep in the evening. The father is God, the child's room is heaven, the child is a collective of God-loving people:

Tam to Bóg szczęśliwiej i pieszczeniej ukochanych świętych swoich do siebie przytula, do serca przyciska, w sercu swoim ojcowskim miłosnym łóżeczko miłości wyściela i na niem kochające siebie dusze uspakaja, miłosnymi rozmowami delektuje, na ręku piastuje, Boskie ucałowania daje (It is there that God more happily and caressingly holds His beloved saints close to Himself, presses them close to His heart, cushions their bed of love in His paternal heart of love and there calms their loving souls, delights them with amorous conversations, holds them in His arms and gives them divine kisses) [2].

This way of activating the imagination is often the final chord of a long and arduous process of meditation, the work of the mind, an essential element because it serves to bring the truths of faith in a close and understandable way to every human being.

\section{Conclusion}

The texts of meditative meditations quoted in this essay were written several hundred years ago. Regardless of the degree of their literary artistry and the literary values attributed to them, they all have the value of a document of human thought and the human spirit. They are also an undeniable part of the great cultural heritage of Poland and Europe. A legacy that can and should enrich the whole human family, the whole world of culture. All of them also prove that the expression of love, irrespective of the ideological and artistic way it is expressed, constitutes the centre of the relationship between God and man, between man and God, and finally between men themselves. In the perspective of the tradition of faith, one can see a testimony to supernatural love in these records; in the temporal and existential philosophy, they become the art of words, inscribed in the grand tradition 
of artists speaking about love, human eroticism, and above all, about the strength and beauty of human love. The individual parts discuss the compositional, linguistic and artistic qualities of the texts in question: from the verbal way of expressing the state of being in love, through the characteristics of the most frequent motifs building the past of the texts under the sign of ars amandi, to the reflections of stylistic and linguistic significance. In addition, the quoted extracts from the seventeenth- and eighteenth-century meditative records open up our imagination, pointing to and proving the continuity and persistence of cultural traditions, for example, by reviving images of the past in contemporary literary realizations or, more broadly, artistic realizations.

\section{Abbreviations}

Rkps - manuscript

B. O. (Biblioteka Ossolineum) - Ossolineum Library

\section{Appendix}

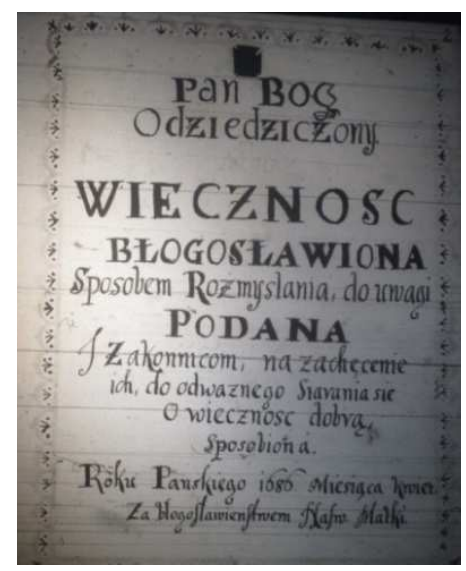

Figure 1. Ossolineum Library, MS 12122/I. Stanisław Józef Porzęcki [Porzycki], Pan Bóg odziedziczony wieczność błogosławiona sposobem rozmyślania do uwagi podana i zakonnicom na zachęcenie ich do odważnego starania się o wieczność dobrą, sposobiona. Roku pańskiego 1686 miesiąca kwietnia, Za błogosławieństwem Najśw. Matki.

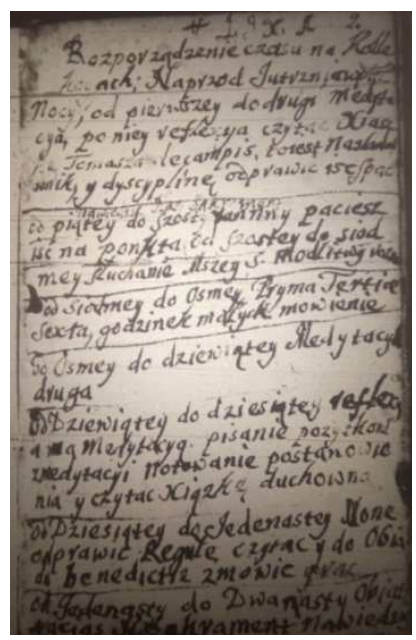

Figure 2. Ossolineum Library, MS 2907/I. Sposób wzywania pomocy od Pana Boga.

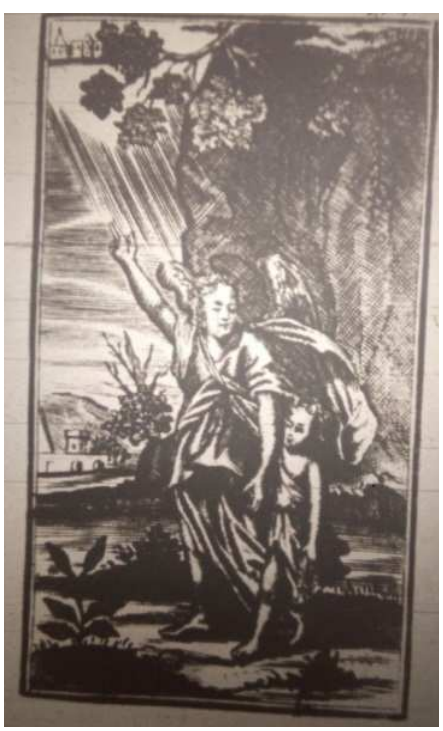

Figure 3. Ossolineum Library, MS 2906/I. Książka ćwiczenia duchownego do nabożeństwa należaca.

\section{References}

[1] Rkps B. O. 1203/I (Zwierciadło żywota duchownego), sheet 12, sheet 14 .

[2] Rkps B. O. 12122/I (Stanisław Józef Porzęcki [Porzycki], Pan Bóg odziedziczony wieczność błogosławiona sposobem rozmyślania do uwagi podana i zakonnicom na zachęcenie ich do odważnego starania się o wieczność dobrą, sposobiona. Roku pańskiego 1686 miesiąca kwietnia, Za błogosławieństwem Najśw. Matki), sheet 62, sheet 75.

[3] Rkps B. O. 1266/I (Zabawa i przygotowanie do przyścia Syna Bożego wypisana roku pańskiego 1741 dnia 24 czerwca przez Antoniego Sobieszczańskiego), sheet 3.

[4] Rkps B. O. 1267/I (Exercitia duchowne złożone od w. o. Bonawentury od św. Stanisława, definitora prowincjalnego prowincjej polskiej), sheet 21.

[5] Rkps B. O. 1270/I (Zabawa roztropnej białejgłowy opisana od Ducha św., by w przypowieściach uważała ścieżki domu swego), sheet 77, sheet 64 , sheet 42 , sheet 39 .

[6] Rkps B. O. 1705/I (Medytacje w czasie odprawiania rekolekcji), sheet $67-68$, sheet 67 .

[7] Rkps B. O. 2358/I (Medytacyje zebrane dla odprawujących zabawy duchowne czyli rekolekcyje roku pańskiego 1748 dnia 8 lipca wypisane), sheet 8 , sheet 65 .

[8] Rkps B. O. 2881/I (Oficjum abo godzinki Panny Maryjej według porządku braciej zakonu karmelitańskiego), sheet 250 , sheet 268 , sheet 247 , sheet 248 .

[9] Rkps B. O. 2882/I (Krótkie zebranie rekolekcyj), sheet 5.

[10] Rkps B. O. 2889/I (Medytacje na cały tydzień), sheet 6, sheet 51.

[11] Rkps B. O. 2906/I (Książka ćwiczenia duchownego do nabożeństwa należąca), sheet 212, sheet 216.

[12] Rkps B. O. 2907/I (Sposób wzywania pomocy od Pana Boga), sheet 12 . 
[13] Rkps B. O. 2910/I (Część synogarlice służąca do rozmyślania na post o Męce Pańskiej), sheet 4, sheet 7.

[14] Rkps B. O. 2942/I (Przygotowanie do świąt uroczystych na rok cały).

[15] Rkps B. O. 3284/I (Zodiak niebieski jaśniejszym nad słońce Słowa wcielonego światłem objaśniony albo rozmyślania na wszystkie całego roku niedziele $\mathrm{z}$ ewangelicznych tekstów zebrane przez jednego $\mathrm{z}$ braci mniejszych kapłana w roku 1713), sheet 19.

[16] Rkps B. O. 3291/I (Ręka Boska do prowadu zbawiennego nam gotowa), sheet 4 , sheet 5 , sheet 24 , sheet 9 , sheet 92 , sheet 91 .

[17] Rkps B. O. 4267/I (Nowenna ku czci Najśw. Serca Jezusowego), sheet 32, sheet 33, sheet 34, sheet 39 .

[18] Rkps B. O. 4387/I (Punkta na mortyfikacją), sheet 9.

[19] Rkps B. O. 5375/I (Zebranie o Męce Pańskiej nabożeństwa i ćwiczenia duchownych na kwadragesymę $\mathrm{z}$ wiela ksiąg drukowanych [...] to wszystko w tę książkę zgromadziwszy napisano w klasztorze płockim), sheet 187 , sheet 445 , sheet 446 , sheet 246 , sheet 74 , sheet 74 , sheet 75 , sheet 439 , sheet 439 , sheet 440 , sheet $186-187$, sheet 5 .

[20] Rkps B. O. 6936/I (Zabawa codzienna powołanych na Służbę Boską to jest informacyja o codziennym nabożeństwie, zwyczajach, obligacyjach i powinnościach zakonnych córkom ojca św. i patryjarchy Dominika ćwiczącym się w doskonałości duchownego życia służąca, pilnością i staraniem Najprzewielebniejszej w Bogu Matki Dominiki Chomentowskiej, mistrzyni powtórnej Nowicyjatu Żółkiewskiego WW. Panien Dominikanek Prowicyi ruskiej św. Jacka dla wygody nowicyjackiej $\mathrm{z}$ starego manuskryptu konfirmującego się konstytucyjom zakonnym przepisana Roku Pańskiego 1762 dnia 10 miesiąca stycznia), sheet 194, sheet 45.

[21] Rkps B. O. 946/I (o. Jana a Jesu Maria karmelity bosego Nauka o modlitwie), sheet 194, sheet 178.

[22] Benedykt z Nursji św. (1997), Reguła; św. Grzegorz Wielki, Dialogi. Księga druga, translated by A. Świderkówna, Kraków, pp. 91-17.

[23] Kowalska M. Faustyna bł., s. (1999), Dzienniczek. Miłosierdzie Boże w duszy mojej, Warszawa.

[24] Bernard z Clairvaux św. (1991), O miłowaniu Boga, translated from Latin by S. Kiełtyka, Kraków, p. 123, p. 53.

[25] Tomasz à Kempis (1984), O naśladowaniu Chrystusa, translated by A. Kamieńska, preface - ks. J. Twardowski, Warszawa, p. 111.

[26] Listy mistyczne o. Jana od Jezusa i Maryi (Dokument sztuki przekładowej z XVII wieku ze zbioru rękopisów Biblioteki im. Ossolińskich we Wrocławiu). prepared and edited by Beata Łukarska (2015), Częstochowa, sheet 121-122, sheet 123, sheet 129.

[27] Adamska J. I. (1983), Święta Teresa od Jezusa, Kraków, p. 288.

[28] Adamska J. I. (1994), Krzak gorejący Kościoła. Święty Jan od Krzyża, Poznań.

[29] Bednarz M. (1994), Duchowość św. Ignacego Loyoli, in: Duchowość zakonna. Szkice, ed. J. Kłoczowski. Zakony w
Polsce. Katalog, compiled by J. Kozak, Kraków 1994, pp. 102 115.

[30] Blusiewicz A. (1985), Ogień miłości. Z przemyśleń nad recepcją „Pieśni nad Pieśniami” w polskiej poezji barokowej, Przeglad Powszechny, 7/8, pp. 129-135.

[31] Bouyer L. (1982), Wprowadzenie do życia duchowego. Zarys teologii ascetycznej i mistycznej, translated by L. Rutowska, Warszawa.

[32] Gori N. (2013), Maria Magdalena De’Pazzi. Niecierpliwość Bożej miłości, Poznań, pp. 58-59.

[33] Górski K. (1980), Kierownictwo duchowe w klasztorach żeńskich w Polsce XVI-XVIII wieku. Teksty i komentarze, Warszawa, pp. 251-260.

[34] Hojnowski J. SCJ (2006), Mały słownik Kultu Serca Jezusowego, Kraków, pp. 60-61.

[35] Kłoczowski J. A. (2001), Drogi człowieka mistycznego, Kraków, p. 115.

[36] Leszczyński Z. (1988), O inspiracji biblijnej przenośnych znaczeń serca, in: O języku religijnym. Zagadnienia wybrane, ed. M. Karpluk, J. Sambor, Lublin, pp. 145-165.

[37] Łapiński Z. (2009), Widziane, wyobrażone, pomyślane, Teksty Drugie, 1/2, pp. 46-55, pp. 47-56.

[38] Makuchowska M. (1998), Modlitwa jako gatunek języka religijnego, Opole, pp. 105-106.

[39] Misiurek J. (1984), Pojęcie i podstawy kultu Serca Jezusowego według polskich teologów katolickich XVII i XVIII wieku, Roczniki Teologiczno-Kanoniczne, 2, p. 74, pp. 93-105.

[40] Misiurek J. (1992), Zarys historii duchowości chrześcijańskiej, Lublin, p. 65.

[41] Olejnik S. (1999), Teologia moralna życia osobistego, Włocławek, pp. 214-217.

[42] Rembowska-Płuciennik M. (2009), Wizualne efekty i afekty. Obrazowanie mentalne a emocjonalne zaangażowanie czytelnika, Teksty Drugie, 1/2, pp. 120-134, pp. 120-133.

[43] Squire A. (1981), Pytając Ojców, translated by J. Sulowski, Warszawa, p. 163.

[44] Szczaniecki P. (1989), Benedyktyni polscy. Zbiór szkiców i opowiadań, Tyniec, p. 58.

[45] Vuarnet J.-N. (2015), Ekstazy kobiece, translated by Matuszewski, Gdańsk, pp. 101-111.

[46] Wichowa M. (2010), Dzieło Diega de Estella. O wzgardzie świata i próżności jego w przekładzie ks. Augustyna Kochańskiego jako poradnik medytacji. Problemy komunikacji literackiej, Łódź.

[47] Wider Dominik od Matki Boskiej Różańcowej OCD, o. (1994), Duchowość karmelitańska, in: Duchowość zakonna. Szkice, ed. by J. Kłoczowski. Zakony w Polsce. Catalog, compiled by. J. Kozak, Kraków, pp. 82-94.

[48] Wilkoń A. (2002), Dzieje języka artystycznego w Polsce. Język i style literatury barokowej, Kraków, pp. 14-147. 